\title{
INFORMATION-ANALYTICAL PROVISION OF FINANCIAL SECURITY OF INDUSTRIAL ENTERPRISES: DETERMINANTS, EVALUATION OF INDICATORS AND MECHANISMS OF STRENGTH
}

\author{
OKSANA VIVCHAR, JUSTYNA KRZYWKOWSKA, LILIIA MYKHAILYSHYN, OKSANA KOHUT-
} FERENS

\begin{abstract}
Conceptual aspects of industrial enterprises financial security are considered, features of industrial enterprises financial security information and analytical support functioning are determined. On the basis of which a structural and logical scheme of information and analytical support of an industrial enterprise financial security in modern transformational conditions is proposed.

The analysis of the current state of major external and internal threats identification is carried out. Based on the results of the analysis, it was found that the most risky components of an industrial enterprise financial security are investment and credit, since these components carry the greatest number of risks.

Also, a comprehensive analytical assessment of the information and analytical support formation of the country's Western region business structures financial security was made. The calculations make it possible to identify the main problematic aspects of the functioning of enterprises and threats to their financial security and to develop measures to strengthen it. The economic efficiency of the information and analytical support system introduction of industrial enterprises financial security with consideration of strategic and tactical vectors of development, and also depends on completeness, reliability, timeliness of the information component. The algorithm of forming information and analytical support of industrial enterprises financial security assessment with consideration of software is investigated. On the basis of which a multi-vector mechanism of information and analytical support of industrial enterprises financial security in modern conditions of turbulence of economic processes is proposed. This will make the decision-makers informed, both strategic and tactical, operational.
\end{abstract}

Keywords: financial security, information, information and analytical support, threats to financial security, industrial enterprises, multi-vector mechanism of information and analytical security of industrial enterprises financial security. 


\section{INTRODUCTION}

Relevance. In today's post-conflict conditions, the development of business structures of the industry remains unsatisfactory. It cannot be overlooked that industrial enterprises operate in an unstable and dynamic external environment, under the influence of information technologies, which create threats and dangers to the effective functioning of economic entities. It should be noted that in conditions of uncertainty and volatility of the environment, the problem of strengthening the financial security of an industrial enterprise in the context of information and analytical support is of particular relevance. Undoubtedly, in such circumstances, it is a prerequisite for developing advisory aspects to improve the information and analytical support of financial security of industrial enterprises financial security.

The purpose of the study is the development of theoretical and applied aspects to improve the information and analytical support of industrial enterprises financial security in the current conditions of business macrotrends.

In an environment of industrial enterprises instability, when the lack of resources to finance their activities threatens not only the ability to support the process of extended reproduction, but also their viability, the issue of protecting the interests of the enterprise from the negative impact of external and internal threats becomes more relevant. In today's transformational environment, it is a well-known fact that im proving the information and analytical support of industrial enterprises financial security is not a single process. Therefore, it should be considered as a set of interrelated mechanisms and methods of the structural and logical aspects of information and analytical support organizing individual elements in the context of strengthening financial security. It should be noted that the study of the industrial enterprises financial security is of particular relevance due to the rise in cost of the resource base, increased energy intensity of production, the economic crisis in the country and the constant fluctuations in pricing policies for industrial products. Significant contribution to the research of scientific problems on the formation of information and analytical support of industrial enterprises financial scurity was considered in the works of such economists as O. Arefiev, B. Andrushkiv, O. Baranovsky, Y. Bilokomirova, O. Vivchar, T. Ganushchak, K. Goryacheva, L. Donets, T. Zavora, D. Kislov, B. Kartich, S. Melnyk, N. Reverchuk, O. Stepanova, S. Tsyuryupa, O. Yaremchuk and others. It should be noted that the issues of the industrial enterprises financial security concept implementation were reflected in the works of some scientists, in particular O. Gryvkivska, N. Davydenko, O. Zakharova, P. Prichunov, M. Yaremova.

\section{RESULTS}

International experience shows that effective management of information support for industrial enterprises is one of the most important ways of strengthening financial security in the way of overcoming many destructive phenomena in the national economy. Progressive innovative systems and ideological and methodological vision of the conceptual aspects of information support is a recognized tool for industrial enterprises financial security. Based on the literature we have analyzed, we can conclude that economic theory today identifies two main approaches to determining the essence of enterprises financial security. According to the first approach, financial security is considered as one of the most enterprise's economic security important component. The second approach emphasizes the need to distinguish financial security as an independent object of research and management.

According to the dynamic development of scientific opinion, O.I. Baranovsky noted that the enterprise financial security is the degree of financial interests protection at all levels of financial relations or the level of providing the enterprise with financial resources sufficient to meet its needs and fulfill its existing obligations. [1, p.84]. The results of our research, summarizing the views of scientists on financial security, allow us to consider the financial security of an industrial enterprise in several aspects. 
Thus, analyzing the main approaches of leading economists to interpret the financial security of an industrial enterprise, we can say that the main characteristics of financial security are: resistance to internal and external dangers and threats; availability of sufficient financial resources; financial equilibrium, stability, liquidity and solvency in the short and long term; meeting the needs of the enterprise for financial resources for sustained expanded reproduction of activities; the ability to respond timely to internal and external hazards that could cause damage to the business or lead to its elimination; sufficient financial independence and protection of the business owners financial interest; sufficient flexibility in making financial decisions.

In the context of the problem under study, it can be noted that ensuring financial security, an important element of which is considered to be its information and analytical component. In our opinion, it is one of the most important tasks of the industrial enterprise management.

A constructive analysis of theoretical developments suggests that there are many interpretations of the term "information". It is a well-known approach, in particular S. Tsyurupa, believes that information is one of the most important resources together with material, energy and human resources. [12, p. 231]. However, it should be noted that B. Kortich states that information is certain information, a set of any data, knowledge [8, c.41]. Please note that the interpretation data have the right to exist, do not negate each other, but only supplement.

It should be noted at the same time that according to O. Susidenko, the information-analytical subsystem of the industrial enterprise financial security should contain the following data: qualitative and quantitative values of financial security indicators, presence or potential of risks and threats, formalized financial interests and status of their realization, strategic plan (strategy) of ensuring of the enterprise financial security, qualitative and quantitative parameters of the financial resources use, the volume of the latter, as well as their sources of income, financial plan (budget).

It should also be noted that external sources of information contain data on: level of the country's macroeconomic development and industry to which the enterprise belongs; financial market conditions; activity of competitors (suppliers, buyers, banks, insurers); industry performance indicators of analogous enterprises; assessment of threats to financial security of entrepreneurial activity by source, by severity of consequences, by probability, by sphere and source of occurrence, by duration of exposure, by degree of development, by degree of tension, etc. [5].

It should be emphasized that complete, timely and reliable information will allow you to make effective decisions to prevent and overcome all kinds of threats to the financial interests of economic entitiesBased on the literature we have worked out, we have formed a structural and logical scheme of information and analytical support for the industrial enterprise financial security (Fig. 1). 


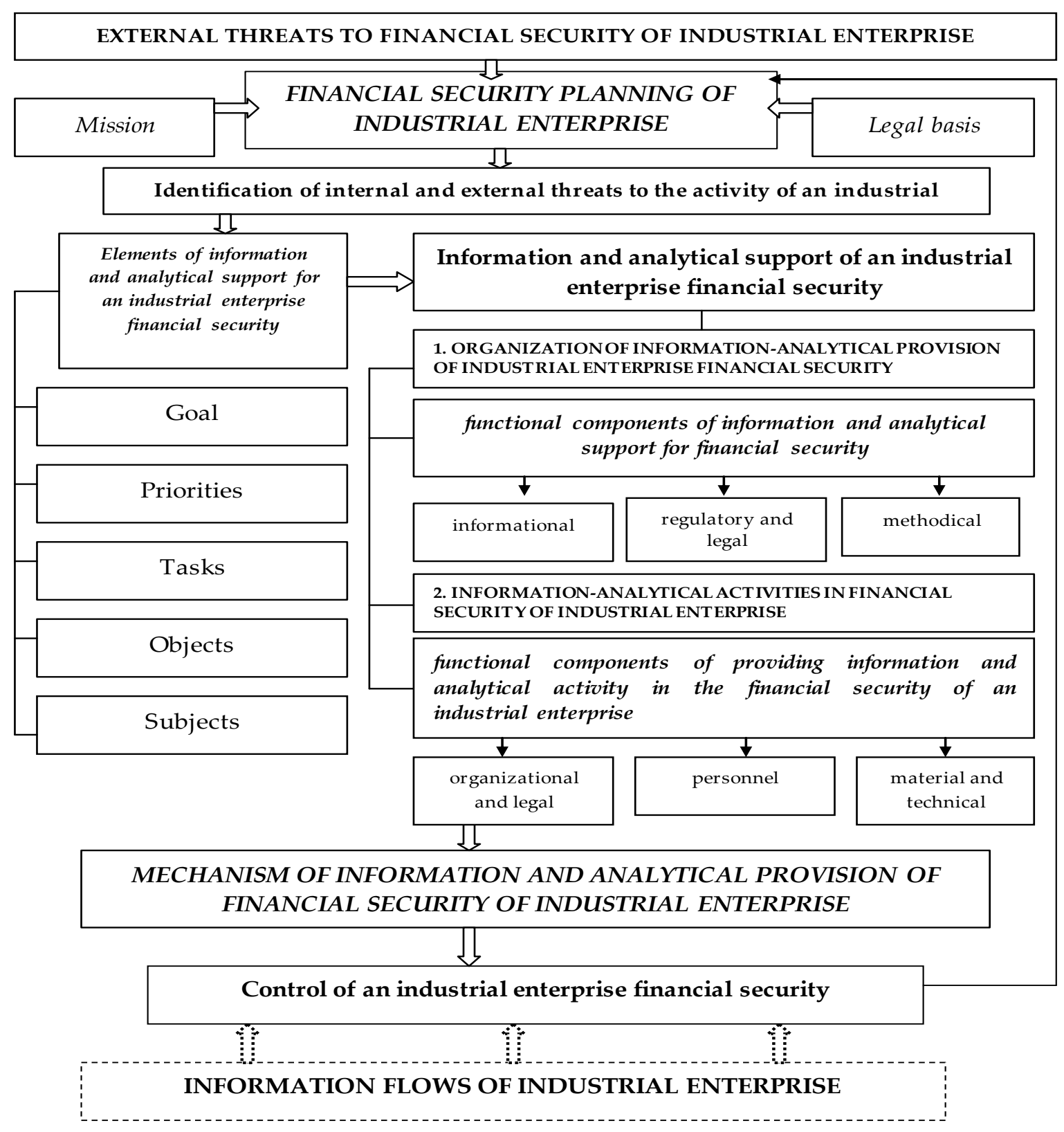

Fig. 1. Structural-logical scheme of information and analytical of an industrial enterprise financial security [author's development]

In the meantime, it should be noted that minimizing the risks of loss of information flows in an industrial enterprise and timely identification of threats that will negatively or likely have an impact on, prevent and counteract the activities of the entity in the future.

In today's turbulence of economic processes, priority should be given to maintaining economic stability and economic growth as a basis for national security, which is determined by the level of security of particular sectors of the economy, including industry.

One of the important components of economic security is financial, without which it is practically impossible to effectively carry out business activities in this field. On the basis of the conducted scientific researches it is noted that according to L. Golovkova, the main goal of the enterprise financial security in the industrial complex is stable maximum effective providing of high potential of market value development and maximisation and growth of the enterprise capitalisation in the future. To achieve this goal, in the author's view, it is necessary to identify the following basic goals: ensuring high technological development potential; ensuring transparency of financial reporting and legal protection; maximizing the market value of industrial enterprises by attracting additional sources of 
financing; ensuring the stability of the financial state through financial independence, liquidity, preservation of property values of enterprises $[2,4]$.

It should also be noted that one of the determining factors influencing the formation of industrial enterprises financial security is the presence of internal and external threats in the financial sphere. In this aspect, $\mathrm{O}$. Gryvkivska notes that the most important is the division of threats into internal and external, since such separation makes it possible to identify the source (place) of the threat, the subject causing it, the development in space, the nature of its occurrence (objective). , subjective), the ability to influence it, the level of controllability [6].

From a practical point of view, if internal threats directly depend on the financial strategy and tactics of the enterprise, the skills of workers and the sectoral strategy, and therefore can be identified and corrected, then external threats reflecting the financial and economic situation in the country, in some of its parts cannot be detected in time and, consequently, localized. It is worth pointing out the researches of O. Gryvkivska, E. Kartuzov, L. Matviychuk and others, who state that in order to ensure the financial security of an industrial enterprise, it is advisable to create a system of threat monitoring and prevent the impact of such risks by methods of insurance, redundancy, diversification and limit.

In the context of post-crisis recovery, the inflation rate, em ployment rate, international balance of payments, and the stability of the national currency should be constantly evaluated during the external environment analysis. In the framework of analytical research, we propose to classify by the main functional components of financial security of an industrial enterprise and carry out their division into internal and external (Tab. 1).

\begin{tabular}{|c|c|c|}
\hline $\begin{array}{l}\text { Classification } \\
\text { components of } \\
\text { threats }\end{array}$ & External threats & Internal threats \\
\hline Budget and tax & $\begin{array}{l}\text { - increasing fiscal pressure on an } \\
\text { industrial enterprise; } \\
\text { - instability of fiscal legislation. }\end{array}$ & $\begin{array}{l}\text { - low level of payment and settlement } \\
\text { discipline; } \\
\text { - ineffective management of the } \\
\text { accounts receivable and payable of } \\
\text { the enterprise on payments with the } \\
\text { budget; } \\
\text { - inefficient tax management }\end{array}$ \\
\hline Insurance & $\begin{array}{l}\text { - increase of insurance tariffs; } \\
\text { - delays in insurance payments; } \\
\text { - insurance fraud; } \\
\text { - imperfection of the regulatory } \\
\text { framework in the field of insurance. }\end{array}$ & $\begin{array}{l}\text { - choice of financially unstable and } \\
\text { unreliable insurance companies; } \\
\text { - ineffective management of the } \\
\text { accounts payable of the enterprise on } \\
\text { insurance payments; } \\
\text { - low level of property insurance. }\end{array}$ \\
\hline Investment & $\begin{array}{l}\text { - imperfection of legislation in the field } \\
\text { of investment; } \\
\text { - deterioration of the investment climate } \\
\text { in the country; } \\
\text { - reduction of interest rates on deposits; } \\
\text { - the probability of non-return of some } \\
\text { or all of the deposit resources; } \\
\text { - imperfection of the legislation } \\
\text { governing banking activities; } \\
\text { - absence of a deposit guarantee fund for } \\
\text { legal entities. }\end{array}$ & $\begin{array}{l}\text { - decrease of investment } \\
\text { attractiveness of industrial enterprise; } \\
\text { - inefficient investment policy of an } \\
\text { industrial enterprise; } \\
\text { - irrational depreciation policy; - } \\
\text { limited diversification of industrial } \\
\text { enterprise deposits; } \\
\text { - choice of financially unstable and } \\
\text { unreliable banking institutions when } \\
\text { entering into deposit agreements. }\end{array}$ \\
\hline
\end{tabular}




\begin{tabular}{|c|c|c|}
\hline $\begin{array}{l}\text { Classification } \\
\text { components of } \\
\text { threats }\end{array}$ & External threats & Internal threats \\
\hline Stock & $\begin{array}{l}\text { - decrease in the market value of } \\
\text { securities issued by the enterprise; } \\
\text { - low rates of realization of the issued } \\
\text { securities. }\end{array}$ & $\begin{array}{l}\text { - sub-optimal distribution of profit } \\
\text { between consumption by owners and } \\
\text { reinvestment of it in the assets of the } \\
\text { enterprise; } \\
\text { - inefficient dividend policy of an } \\
\text { industrial enterprise. }\end{array}$ \\
\hline Cash & $\begin{array}{l}\text { - devaluation of the national currency; } \\
\text { - NBU's (National bank of Ukraine) } \\
\text { imperfect monetary policy; } \\
\text { - rising inflation; } \\
\text { - crisis of the monetary system of the } \\
\text { state; } \\
\text { - high level of exchange rate volatility. }\end{array}$ & $\begin{array}{l}\text { - decrease in sales revenue; } \\
\text { - lack of own working capital; } \\
\text { - violation of the organization of } \\
\text { saving money; } \\
\text { - breach of payment discipline, } \\
\text { ineffective management of accounts } \\
\text { receivable and payables. }\end{array}$ \\
\hline Credit & $\begin{array}{l}\text { - increase in interest rates on loans; } \\
\text { - increasing the requirem ents for } \\
\text { creditworthiness of borrowers; } \\
\text { - financial market instability; } \\
\text { - crisis of the financial and credit system } \\
\text { of the state. }\end{array}$ & $\begin{array}{l}\text { - reducing the solvency of an } \\
\text { industrial enterprise; } \\
\text { - unreasonable increase in the amount } \\
\text { of borrowed capital; } \\
\text { - slowing down of accounts payable; } \\
\text { - ineffective credit policy. }\end{array}$ \\
\hline
\end{tabular}

Tab. 1. Systematization of major threats to the financial security of an industrial enterprise

Based on the results of the analysis, we found that the most risky components of an industrial enterprise financial security are investment and credit, since these components carry the greatest number of risks.

Please note that the stage of assessing the major financial threats that have an impact on financial security should be taken into account when developing a comprehensive system for assessing the financial security level of an industrial enterprise. Ensuring an adequate level of financial security for an industrial enterprise depends on its own conception of financial security management, which should be based on the development of financial security management strategy, financial security management policy and mechanism of financial security management of the enterprise, taking into account the information and analytical component. [11].

It should be noted that the effectiveness of any industrial enterprise depends to a large extent on complete, reliable and timely information and analytical support. In such circumstances, with effective management, the information and analytical support system will increase the level of profit management and as a consequence of strengthening the financial security of business structures of industry [10].

According to N. Davydenko's scientific interpretations, the financial security of industrial enterprises is influenced by certain factors, in particular: industry diversification; optimal capital structure; high level of capitalization; taking into account risks of industrial activity, seasonality and minimization of negative consequences [7, p.60]. Note that it is industrial enterprises that are particularly vulnerable to external threats. In view of this, the study of the information and analytical support problem of industrial enterprises financial security is timely and relevant.

The leading industrial enterprises of the Western region of the country have formed separate information-analytical units, which are engaged in collecting, processing and interpretation of the 
necessary information on the internal and external environment. Their experience shows that the creation of a system of information and analytical support in an enterprise is accompanied by both a certain increase in its tangible assets (eg, hardware) and, first of all, intangible assets. Analysis of some information activities aspects and analytical units of leading industrial enterprises allows us to establish that one of the determining indicators of financial security of these enterprises is profitability indicators. It should be noted that based on the application of the computer program, using the data of the corresponding table, we have formed the results of information processing based on the use of financial security indicators of industrial enterprises in the Western region by type of economic activity and presented in Fig. 2.

Therefore, on the basis of analytical studies, there is a generally positive trend of activity of industrial enterprises in the Western region, which is confirmed by their profit during 2014-2018., the sum of which in 2018. amounted to UAH 1437000.4 thousand, ie increased by UAH 1265816 thousand compared to 2014. The decrease in the amount of net profit in 2016 compared to 2015 by UAH 237638 thousand. or $57.13 \%$ due to the significant increase in expenses including administrative, sales, financial and other expenses.

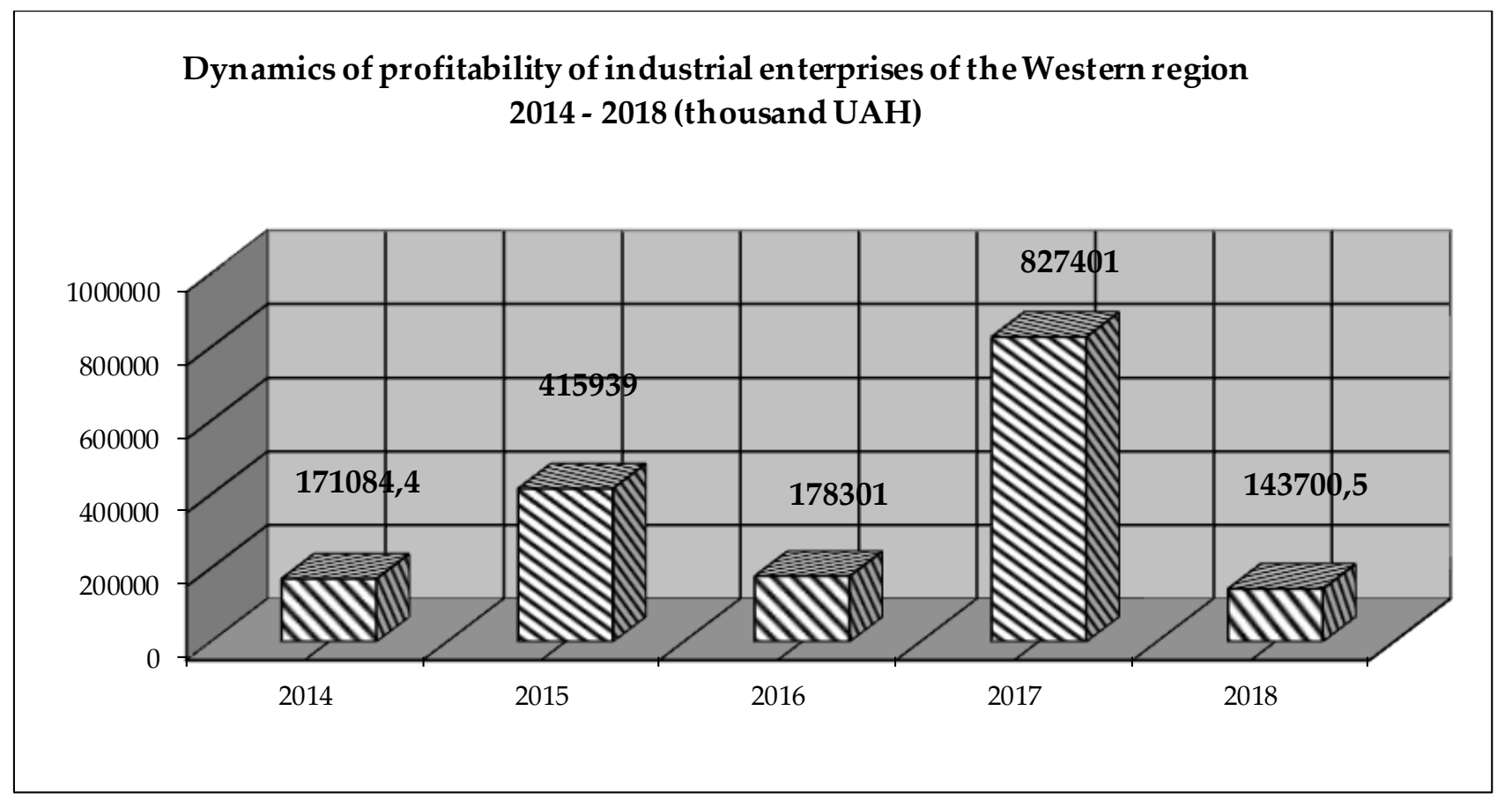

Fig. 2. Analytical evaluation of industrial enterprises financial security indicators of the country's western region, 2014-2018 [calculated by author]

The results of scientific studies confirm the fact that $\mathrm{O}$. Udovenko explains that in contrast to the administrative-command economy, in which the economic security of industrial enterprises in general and financial in particular is provided by vertically constructed methods of total centralized management, the processes of ensuring security in market conditions are dispersed. in many subjects and areas of activity having their own, often opposite interests, not inherent in the previous system. In a new environment, a horizontally dispersed security system begins to prevail [3, p. 127]. All this, in our opinion, requires a rethinking of the traditional methods and means of information and analytical support for the financial security of industrial enterprises. In our opinion, the benefits resulting from the operation of the information and analytical system, and, as a consequence, better management awareness, are most noticeable at the level of industrial enterprises financial security (Fig. 3). 


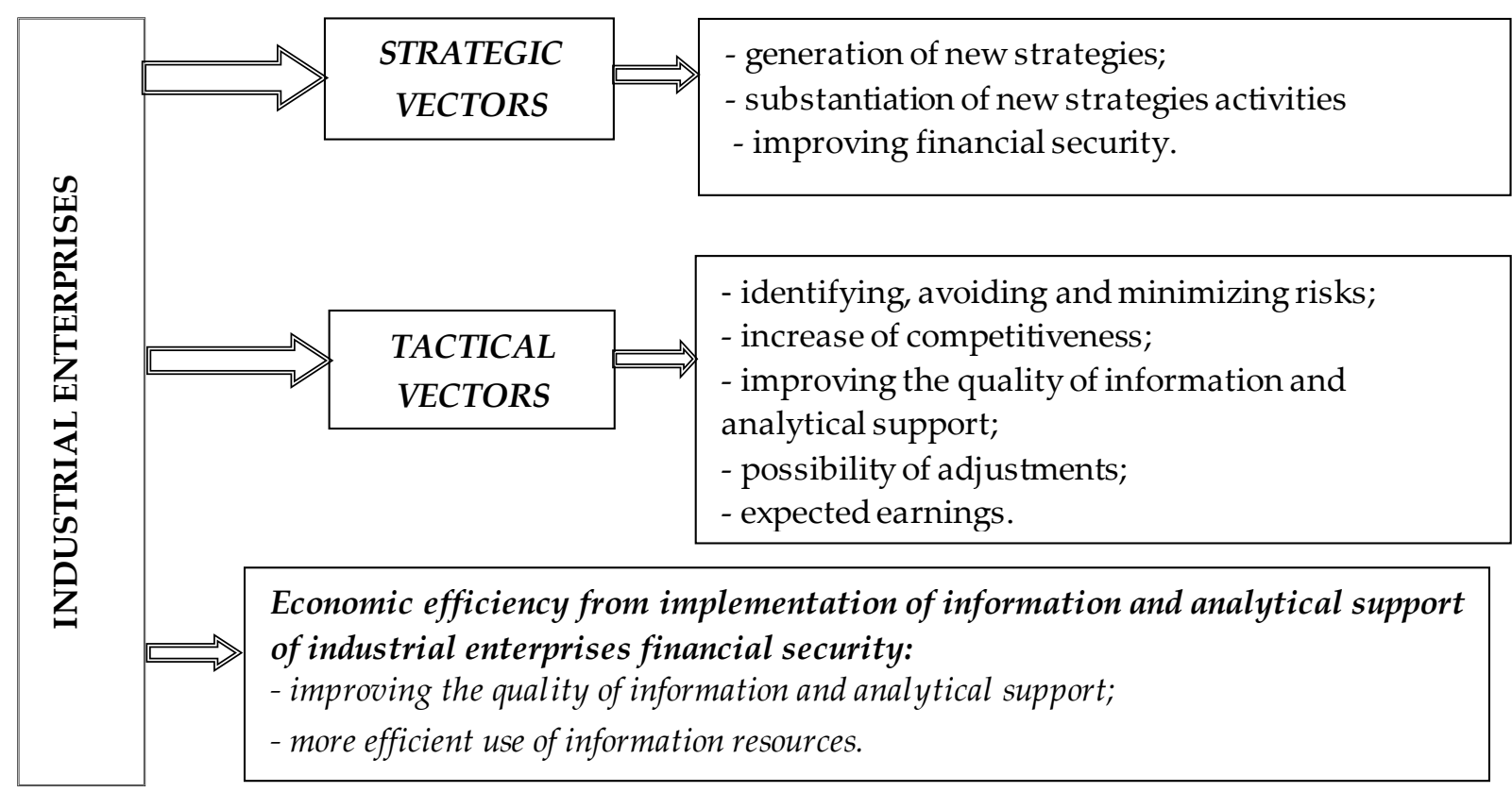

Fig. 3. Economic efficiency from the implementation of the information and analytical support system of industrial enterprises financial security [author's development]

Thus, a properly built information and analytical support system allows to achieve a high level of financial security of industrial enterprises, using innovative technologies and taking into account a number of factors arising from the above mentioned indicators of economic efficiency, and the specifics of an industrial enterprise.

In the conditions of turbulence of economic processes for an effective system of information and analytical security of industrial enterprises financial security, in our opinion, it is necessary that there is an information and analytical unit, which is a component of the security service, whose function is to protect any information of the respective enterprise, to clarify the specifics of functioning inside and outside the enterprise, in a timely manner to receive advance information about vital processes for the enterprise and identify the means of its optimal use Reference.

It should also be emphasized that only computer technology with its high level of operations and software can fulfill these requirements for management information.

We consider it expedient to note that the need for rapid introduction of information and analytical technologies is determined by the following factors: increasing the "intelligence" of management (the rapid availability of large amounts of objective information allows us to make promising project decisions); scheduling optimization (timely access of all interested users to important information contained in one centralized database); improvement of project decision-making processes. Decisions become more grounded if they are backed by reliable and timely information. It also saves time spent on analyzing minor tasks; extension of information competence - the more experts have access to the necessary data, the more effectively the management subsystem as a whole; promotional nature of information about the activity of an industrial enterprise [9].

Common problems with the introduction of information and analytical technologies are that, as a rule, individual tasks of management are automated, resulting in the inability to obtain reliable information on financial and economic indicators in full.

That is why the first and priority principle of building information and analytical systems in industrial enterprises is a systematic approach, according to which the attention should be focused on the whole sphere as a whole, and not on individual spheres, since the specific properties of the object can only be evaluated from the standpoint of the whole systems.

In order to optimize the process of monitoring the financial security of industrial enterprises, we propose to use scientifically designed and tested computer programs, which can be used to quickly assess the level of each component of financial security, determine the impact of the components on its 
overall level and the dynamics of the financial security ratio. The calculations made will allow to identify the main problematic aspects of functioning of enterprises and threats to their financial security and to develop measures for its strengthening. Appropriate software allows you to quickly access online information without additional workforce, since only one specialist can perform security assessments with a computer program.

The algorithm of industrial enterprises software forming is shown in Fig. 4.

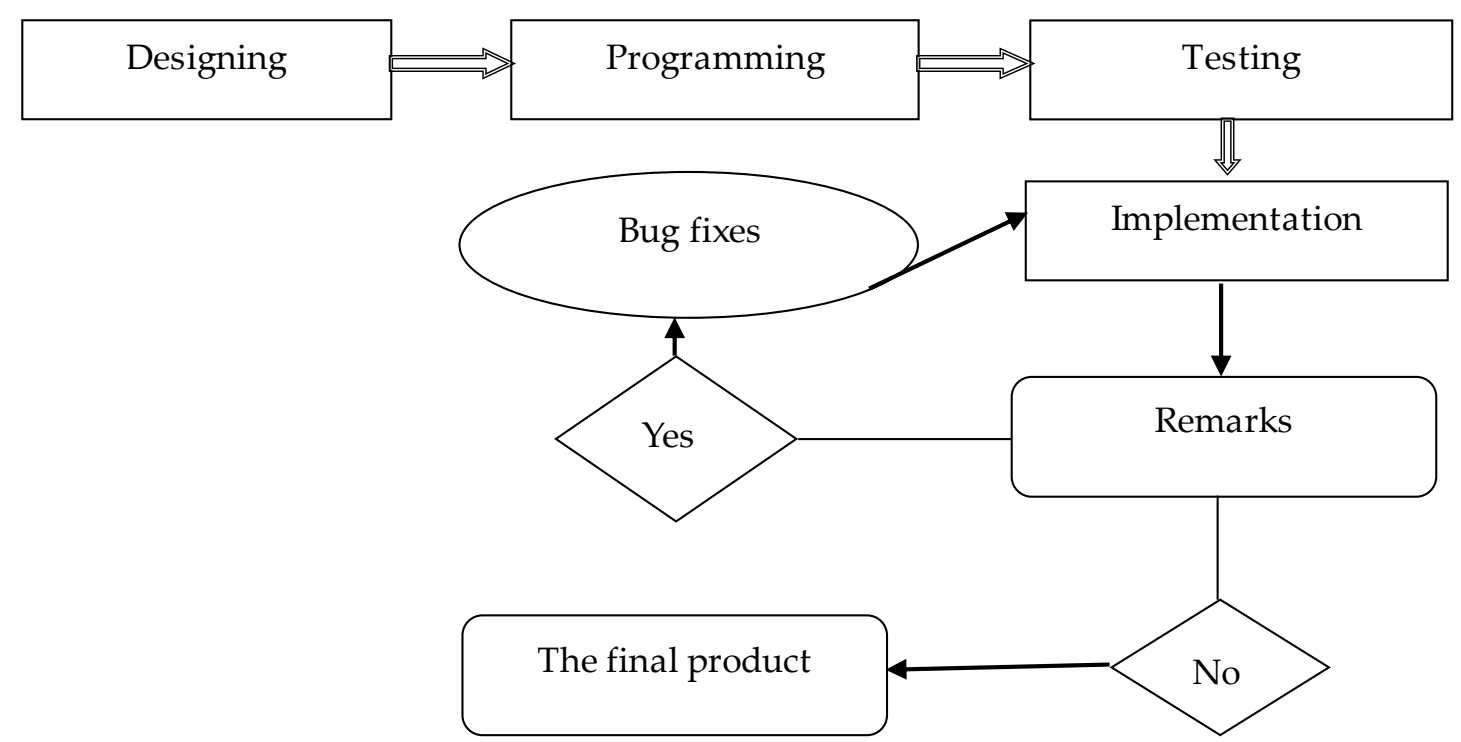

Fig. 4. The algorithm of information and analytical support formation for the assessment of industrial enterprises financial security [37, p.98]

The software greatly facilitates the financial security assessment process, while saving the time and effort of industrial staff. In addition, according to the results of assessing the level of security in the program environment, reports are prepared that are convenient for perception and analysis, which make it possible to assess the level of financial security, the degree and nature of the impact of its individual components and their factors at a particular point in time. Also, data of reports, their graphic representation create conditions for diagnostics and evaluation of financial security, its factors in dynamics. All this together creates the basis for the formation of management vectors for strengthening the industrial enterprise financial security.

The results of this scientific work give us the opportunity to create a multi-vector mechanism for improving the information and analytical support of an industrial enterprise financial security on the basis of which it is necessary: control the likely channels of information leakage at an industrial enterprise; monitor employee access to corporate information resources; to keep archive of operations with documents; detect in the original http-data stream that may threaten the leakage of confidential informatio; control the use of mobile storage devices, information devices and communication ports; archive mail correspondence; monitor file operations level; correct selection of personnel, application of material and moral incentives, creation of favorable social and psychological climate within the organization, creation of opportunities for professional growth, reduction of staff turnover, formation of "firm patriotism" (Fig. 5). However, only timely and comprehensive completion of all these tasks can lead to the desired result. Therefore, the above proposals are the basis for further formation of the information and analytical security system of industrial enterprises financial security.

\section{CONCLUSIONS}

Summarizing the above, it should be noted that information and analytical support is considered as a system that includes a set of methods, tools and methods aimed at collecting, analyzing, protecting information, as well as forecasting, continuous advisory support and making recommendations for 
effective management decisions of operational and strategic. One of the main places in the financial security system is the information and analytical support, since information, its timeliness, reliability, completeness, correct interpretation depends on the efficiency of the industrial enterprise, its safety, competitiveness, and sometimes the fact of functioning on the market. The following subsystems have been interpreted to solve the problems posed by the information and analytical support system: economic intelligence, information security and analytical consulting.

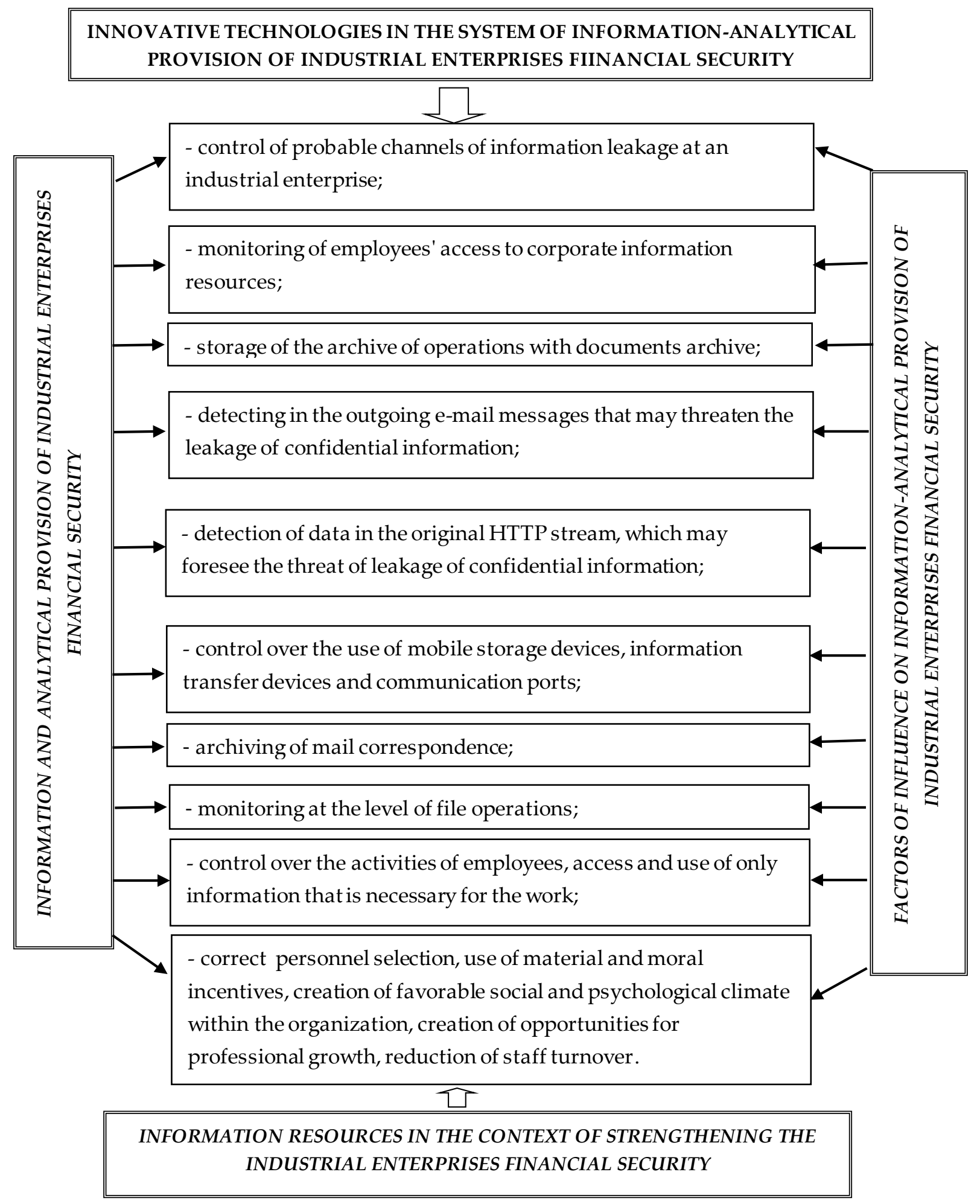

Fig. 5. Multi-vector mechanism of industrial enterprises financial activity information and analytical support [development] 
It should be noted that the results of economic efficiency from the functioning of the information and analytical support system in an industrial enterprise is sufficiently broad and depends on the industry, the specifics of the enterprise. It can be manifested in a better awareness of decision makers, both strategic and tactical, operational. This leads to increased competitiveness of both the industrial enterprise in particular and the level of its financial security. From a practical point of view, we have proposed a multi-vector mechanism for improving the information and analytical support for the financial security of an industrial enterprise based on the use of innovative technologies in modern conditions of turbulence of economic processes.

Therefore, strengthening the financial security of an industrial enterprise is not possible without public policy, since the integrated actions of business entities and the state aimed at maintaining financial security by creating conditions and taking measures to obtain the required level will provide the desired result.

\section{REFERENCES}

[1] Baranovsky O.I. Financial security. Feniks, Kyiv, 1999. (in Ukrainian)

[2] Bilokomirova Ya.M. Information support of economic security of entrepreneurial activity. The Bulletin of Transport and Industry Economics, 29 (2010), 308-312. Available at: http://nbuv.gov.ua/UJRN/Vetp_2010_29_77 (in Ukrainian)

[3] Vdovenko O.S. The Economic Essence of Financial Security of Entrepreneurs in Agrarian Sphere of Economy. Ekonomika APK, 1 (2014), 125-129. Available at: http://nbuv.gov.ua/UJRN/E_apk_2014_1_22 (in Ukrainian)

[4] Ganushchak T.V. Information security of enterprise and conditions of its providing. Odessa National University Herald. Economy, 19 (2/3) (2014), 59-36. Available at: http://nbuv.gov.ua/UJRN/ (in Ukrainian)

[5] Goryacheva K.S. Financial security of the enterprise, essence and place in the system of economic security. Economist, 8 (2003), 65-67. (in Ukrainian)

[6] Grivkivska O.V. Factors of industrial enterprises financial security formation. Agrosvit, 1 (2012), 15-18. (in Ukrainian)

[7] Davydenko N.M. Financial security of industrial enterprise in the system of corporate management. Ekonomika APK, 5 (2013), 58-62. (in Ukrainian)

[8] Kortych B.A. Information Security: Organizational and Legal Basis: Educ. manual . Condor, Kyiv, 2004. (in Ukrainian)

[9] Melnyk S.I. Information security as a component of economic security of the enterprise. Available at http://www.rusnauka.com/6_PNI_2013/Economics/9_130048.doc.htm (in Ukrainian)

[10] Stepanova O.M., Degtyarova L.M. Information security in the conditions of information system development. Available at URL: http://dspace.snu.edu.ua:8080/jkobskaspuibitstream/ 123456789/685/I/II.pdf (in Ukrainian)

[11] Susidenko O.V. Financial security of the enterprise: theory, methods, practice: monograph. TsUL, Kyiv, 2015. (in Ukrainian)

[12] Tsyuryupa S.V. Classification of information and ways of its display for use in the activity of the enterprise. Scientific Notes of "KROK" University, 33 (2013), 228-236. (in Ukrainian)

[13] Yaremova M.I. Improving information support of economic security of industrial enterprises. Sustainable development of economy, 4 (21) (2013), 98-102. (in Ukrainian) 
Address: Oksana Vivchar, Ternopil National Economic University, 11, Lvivska Str. (TNEU Building 1), Ternopil, 46009, Ukraine;

Justyna Krzywkowska, Warminsko-Mazurski University in Olsztyn, 2, Michała Oczapowskiego Str., 10-719 Olsztyn, Poland;

Liliia Mykhailyshyn, Oksana Kohut-Ferens, Vasyl Stefanyk Precarpathian National University, 57, Shevchenko Str., Ivano-Frankivsk, 76018, Ukraine.

E-mail: liliia.mykhailyshyn@pnu.edu.ua, oksana.kohut_ferens@pnu.edu.ua

Received: 03.09.2019; revised: 03.12.2019.

Вівчар Оксана, Кшиковська Юстина, Михайлишин Лілія, Когут Оксана. Інформаційно-аналітичне забезпечення фінансової безпеки промислових підприємств: детермінанти, оцінка індикаторів та механізми зміцнення. Журнал Прикарпатського університету імені Василя Стефаника, 6 (3-4) (2019), $55-66$.

Розглянуто концептуальні аспекти фінансової безпеки промислових підприємств, визначено особливості функціонування інформаційно-аналітичного забезпечення фінансової безпеки промислових підприємств. На основі чого запропоновано структурно-логічну схему інформаційноаналітичного забезпечення фінансової безпеки промислового підприємства в сучасних трансформаційних умовах.

Проведено аналіз сучасного стану щодо ідентифікації основних зовнішніх та внутрішніх загроз. Виходячи із результатів проведеного аналізу, встановлено, що найбільш ризикованими складовими фінансової безпеки промислового підприємства є інвестиційна та кредитна, оскільки дані складові містять у собі найбільшу кількість ризиків.

Також, здійснено комплексну аналітичну оцінку формування інформаційно-аналітичного забезпечення фінансової безпеки підприємницьких структур Західного регіону країни. Проведені розрахунки дають можливість ідентифікувати основні проблемні аспекти функціонування підприємств та загрози їх фінансовій безпеці та розробити заходи щодо ії зміцнення. Обгрунтовано економічну ефективність від впровадження системи інформаційно-аналітичного забезпечення фінансової безпеки промислових підприємств з урахуванням стратегічних та тактичних векторів розвитку, а також залежність від повноти, достовірності, своєчасності інформаційної компоненти.

Досліджено алгоритм формування інформаційно-аналітичного забезпечення оцінки фінансової безпеки промислових підприємств з урахуванням програмного забезпечення. На основі чого запропоновано багатовекторний механізм інформаційно-аналітичного забезпечення фінансової безпеки промислових підприємств в сучасн их умовах турбулентності економічних процесів. Це дасть мождивість здійснювати проінформованість осіб, що відповідають за прийняття управлінських рішень, як стратегічних, так і тактичних, операційних.

Ключові слова: фінансова безпека, інформація, інформаційно-аналітичне забезпечення, загрози фінансової безпеки, промислові підприємства, багатовекторний механізм інформаційноаналітичного забезпечення фінансової безпеки промислових підприемств. 